\title{
Spatial Distribution of Zooplankton Diversity across Temporary Pools in a Semiarid Intermittent River
}

\author{
Thaís X. Melo and Elvio S. F. Medeiros \\ Grupo Ecologia de Rios do Semiárido, Universidade Estadual da Paraíba-UEPB, \\ Rua Horácio Trajano de Oliveira, S/N, Cristo Redentor, 58020-540 João Pessoa, PB, Brazil \\ Correspondence should be addressed to Elvio S. F. Medeiros; elviomedeiros@uepb.edu.br
}

Received 14 January 2013; Revised 17 May 2013; Accepted 19 May 2013

Academic Editor: José Manuel Guerra-García

Copyright (C) 2013 T. X. Melo and E. S. F. Medeiros. This is an open access article distributed under the Creative Commons Attribution License, which permits unrestricted use, distribution, and reproduction in any medium, provided the original work is properly cited.

\begin{abstract}
This study describes the richness and density of zooplankton across temporary pools in an intermittent river of semiarid Brazil and evaluates the partitioning of diversity across different spatial scales during the wet and dry periods. Given the highly patchy nature of these pools it is hypothesized that the diversity is not homogeneously distributed across different spatial scales but concentrated at lower levels. The plankton fauna was composed of 37 species. Of these 28 were Rotifera, 5 were Cladocera, and 4 were Copepoda (nauplii of Copepoda were also recorded). We showed that the zooplankton presents a spatially segregated pattern of species composition across river reaches and that at low spatial scales (among pools or different habitats within pools) the diversity of species is likely to be affected by temporal changes in physical and chemical characteristics. As a consequence of the drying of pool habitats, the spatial heterogeneity within the study river reaches has the potential to increase $\beta$ diversity during the dry season by creating patchier assemblages. This spatial segregation in community composition and the patterns of partition of the diversity across the spatial scales leads to a higher total diversity in intermittent streams, compared to less variable environments.
\end{abstract}

\section{Introduction}

The Brazilian semiarid region represents one of the major dry lands in South America, being characterized by a high hydric deficit and low thermal amplitude [1]. These factors interact with broad climatic patterns to create important variation between dry and wet periods [2]. This affects the hydrology of the region which is characterized by intermittent watercourses [3]. The natural variation associated with the alternation of dry and wet periods and the intermittency of flow in rivers and streams create a mosaic of temporary natural aquatic habitats, mostly strings of ephemeral pools in the dry river bed and more permanent larger ones [4]. Therefore, these systems are highly temporally variable and spatially heterogeneous $[5,6]$.

During the wet season, the mechanical force of the water flow changes the physical habitat and modifies water chemical characteristics and nutrient dynamics $[5,7]$, whereas during the dry season, discontinuation of flow and water volume reduction influence community structure and diversity by concentrating nutrients and affecting physical and chemical characteristics of the water $[5,8]$. Furthermore, during this phase, the water retention in semipermanent and temporary pools represents refugia for the maintenance of aquatic species [9]. These small patchy ecosystems have been argued to contribute disproportionately to the regional assemblage of species given their high local diversity $[10,11]$. This is specially the case for the diversity of the aquatic microinvertebrate fauna which is subject to dispersal limitations that create variation in community composition [12].

The role of dispersion/colonization of species in community composition is associated with the number of species that reach a pool or a suitable habitat and with the order in which these species reach a given habitat [13]. From then onwards species would be sorted out given other factors such as predation [14], species traits [15], and habitat structure [16].

In such pools, specific adaptations and strategies are important to cope with the variable and commonly extreme conditions [17], and such mechanisms may lead to the spatial and temporal segregation of the plankton fauna. Among 
the factors that influence species distribution and assemblage composition of zooplankton, physical and chemical characteristics have been argued to be the most important [18, 19]. Zooplankton assemblages respond rapidly to different water quality conditions most importantly so to temperature, conductivity, $\mathrm{pH}$, and nutrient concentration.

Furthermore, studies have shown that the zooplankton community is sensitive to extreme variation in flow; thus species composition is changed and the succession of taxa is redirected after flow recession [20]. This results in different timing for the emergence of rotifers, cladocerans, and copepods from the inundated dry river beds [21]. However, the role of the hydrological disturbances in the spatial dynamics of zooplankton and the habitat variation in intermittent streams has received little attention. Studies indicate that water flow and its effects on habitat structure play a major role in producing and maintaining a mosaic of pools and microhabitats that can be used for colonization and refugia for aquatic organisms $[22,23]$. This dynamic makes intermittent streams complex and heterogeneous systems, with organisms distributed in patches determined by environmental conditions affecting the fauna hierarchically $[24,25]$.

Therefore, a subdivision of diversity in hierarchical scales in stream ecosystems will result from these factors, which represent the interaction of physical and biological processes. It has been proposed that this hierarchization is represented by macrohabitats, representing distinct morphological zones [26]; mesohabitats, representing pools, runs, and riffles; and the microhabitats, representing stands of macrophytes or submerged vegetation and substrate types [24].

Studies in the aquatic systems of semiarid Brazil show a high diversity of species, including the plankton fauna, and demonstrate that the patterns of diversity are associated with the hydrological extremes and habitat types and/or structure (see $[11,18,27])$. Furthermore, zooplankton plays an important role in the nutrient dynamics and energy flow in dryland river systems [28]. Despite that, studies on patterns of distribution of zooplankton diversity and species composition in dry land intermittent streams are scarce and the effects of the habitat structure on plankton fauna are poorly known (see [11]).

In this study we describe the richness and density of zooplankton across temporary pools in an intermittent river of semiarid Brazil and evaluate the partitioning of diversity across different spatial scales during the wet and dry periods. Given the highly patchy nature of these pools it is hypothesized that the diversity is not homogeneously distributed across different spatial scales but concentrated at lower levels. We also aim to establish the degree of association between environmental variables and the composition of species in the zooplankton assemblages.

\section{Materials and Methods}

2.1. Study Area and Sampling Design. The present study was performed at the Paraíba River basin (Figure 1). This basin encompasses an area of $20072 \mathrm{~km}^{2}$ and its altitudes range from 350 to $460 \mathrm{~m}$ a.s.l. [29]. Predominant vegetation in the basin is the Caatinga, an arboreal to shrubby open forest,

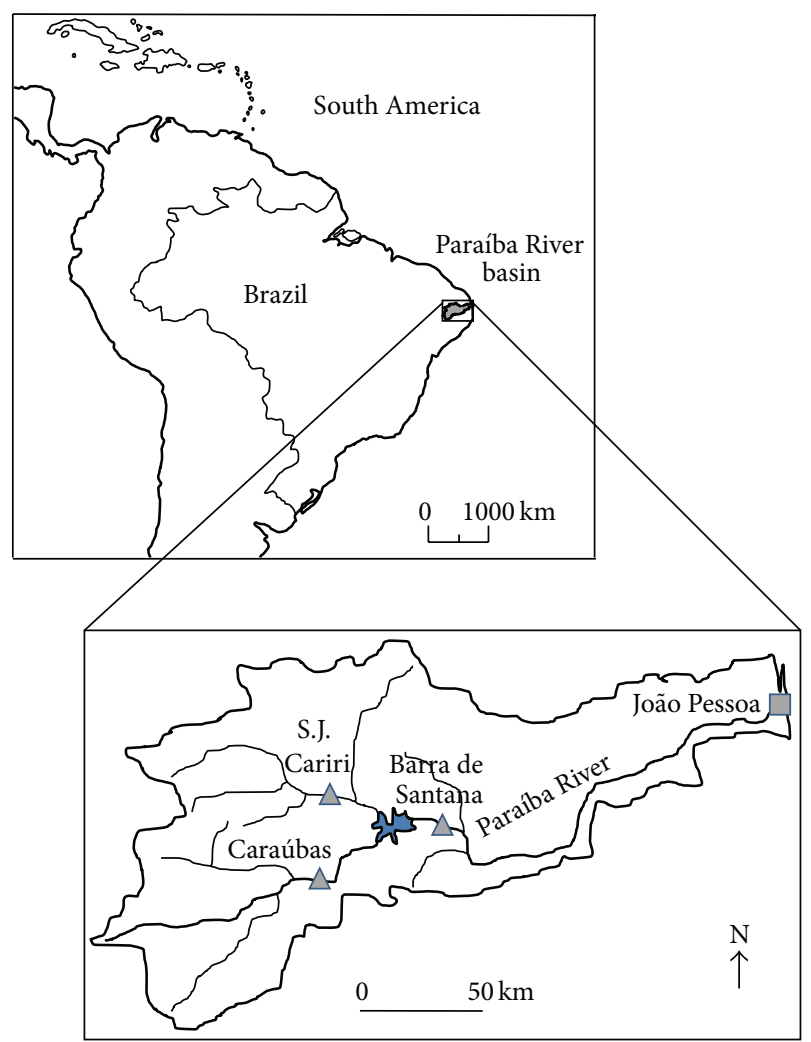

FIGURE 1: Study area showing the location of the Paraíba River basin and the study reaches.

characterized by the presence of xerophytic species [30]. This type of vegetation does not provide strong protection to the soil which increases water losses by evaporation, enhancing the temporal nature of river pools. The climate is classified as semiarid BS'h according to the classification of KöeppenGeiger modified by Peel et al. [31], with average temperature and precipitation of $26^{\circ} \mathrm{C}$ and $600 \mathrm{~mm}$, respectively [32]. The wet season starts in January-February, with higher precipitation between April and June. The peak of the dry season lasts from September to January. The study area is classified as a being of extreme biological importance and identified as priority area for biodiversity conservation in the Caatinga biome [33].

In the study basin, zooplankton was collected from three river reaches of 100 to $500 \mathrm{~m}$ during the wet (June 2010) and dry (October 2010) seasons. These river reaches were located (1) at the Taperoá river, an affluent of the Paraiba River (location at the São João do Cariri municipality, $7^{\circ} 23^{\prime} 0^{\prime \prime} S$; $36^{\circ} 34^{\prime} 24.4^{\prime \prime} \mathrm{W}$ ), (2) at the upper Paraiba River (municipality of Caraúbas, $7^{\circ} 43^{\prime} 29.7^{\prime \prime} \mathrm{S} ; 36^{\circ} 34^{\prime} 9.3^{\prime \prime} \mathrm{W}$ ), and (3) at the lower Paraíba River (municipality of Barra de Santana, $7^{\circ} 31^{\prime} 20.8^{\prime \prime} S$; $36^{\circ} 1^{\prime} 29.8^{\prime \prime} \mathrm{W}$ ) (Figure 1). Henceforth, river reaches will be referred to as the municipality where they run through. At each river reach three habitat samples (10 m tows) were performed and represent different pools or distinct microhabitat types (macrophyte stands, shallow or deeper areas, and rocky outcrops) at the same pool when less than 3 pools were found. From each habitat type sample, three subsamples were taken to account for intrasample variability. 
Zooplankton was collected quantitatively using a plankton net (opening diameter $30 \mathrm{~cm}$, length $70 \mathrm{~cm}$, and mesh size of $60 \mu \mathrm{m})$. The net was towed for a distance of $10 \mathrm{~m}$ on the surface of the water at dusk. To minimize variation in sampling efficiency across samples, velocity and length of tows were similar and the net was washed between each tow to prevent clogging (see [11]). The zooplankton collected was anesthetized with commercial sparkling water and preserved in $4 \%$ formalin. Sucrose was added to the preserved sample to prevent female cladocerans from losing eggs and to minimize carapace distortion [34]. In the laboratory, three sub-samples were taken from each habitat sample and all individuals were identified [35-37] and counted in a Sedgewick Rafter counting cell $(1 \mathrm{~mL})$, and the density was calculated. Only rotifers, cladocerans, and copepods were considered in the present study.

At each river reach, supportive environmental data was collected, comprising physical and chemical water variables, pool morphometry, substrate composition, and the physical structure of the habitat. The physical and chemical variables were estimated using portable meters for $\mathrm{pH}$ (tecnopon mpa$210)$, conductivity $(\mu \mathrm{S} / \mathrm{cm})$ (tecnopon MCS-150), dissolved oxygen $(\mathrm{mg} / \mathrm{L})$, and temperature $\left({ }^{\circ} \mathrm{C}\right)$ (Lutron DO-5510). Transparency $(\mathrm{cm})$ was measured with a Secchi disk and water velocity $(\mathrm{m} / \mathrm{s})$ was measured using the float method [38].

Stream reach morphology was evaluated by the average width $(\mathrm{m})$ and depth $(\mathrm{cm})$ taken from three transects randomly placed in the stream pool. Pool length was also measured and used to calculate pool area. The substrate composition and habitat structure were estimated in 9 to 12 survey points of $1 \mathrm{~m}^{2}$ measured in the margins (see [5]). In each survey point, the proportion of the sediment composition (classified as mud, sand, gravel, and cobbles) and littoral and underwater structures (e.g., macrophytes, grass, submerged vegetation, overhanging vegetation, leaf litter, algae, and woody debris) were estimated visually.

2.2. Data Analysis. Zooplankton diversity was estimated using species richness $(R)$, defined as the total number of species at any given sample, and density $(D)$, defined as the number of individuals per cubic meter $\left(\right.$ ind $\mathrm{m}^{-3}$ ). To test for changes in richness and density across samples a factorial ANOVA was carried out, where each sample measurement of the response variables ( $R$ and $D)$ was classified according to three factors (river reach, habitat sample, and season), where river reach has three factor levels, habitat sample has three factor levels, and season has two levels (wet and dry). In the presence of interaction the next high-order terms were analyzed (reach $*$ season, reach $*$ habitat, and season $*$ habitat) and then the main effects. $A \log _{10}(x+1)$ transformation was applied to the response variables to enhance normality of the data set and equality of variances [39]. Post hoc pairwise comparisons were performed using Tukey's HSD test $(\alpha=0.05)$.

Additive partitioning of diversity was used to decompose the total variation in zooplankton community composition (river reach) into its alpha and beta components. Alpha and beta diversity represent within-unit diversity $(\alpha)$ and between-unit diversity $(\beta)$ on a given scale, respectively.
Zooplankton diversity was analyzed at three different spatial scales: (1) the sub-sample scale, representing individual counts in sub-samples of $1 \mathrm{~mL}$ for each sample $(n=27)$ (this is important to evaluate intrasample variability); (2) the local spatial scale representing the habitats at each reach $(n=9)$ and (3) the regional spatial scale representing the river reach $(n=3)$. Thus, the total diversity $(\gamma)$ was partitioned into the diversity (expressed as percentage) within sub-samples $(\alpha 1)$ and between subsamples $(\beta 1)$, between reach habitats $(\beta 2)$, representing different pools or pool habitats, and between river reaches $(\beta 3)$.

To evaluate temporal (dry/wet season) variation, the data was analyzed separately for each season. The additive partition analyses were performed using PARTITION 3.0 [40], with individual-based randomizations (type I null model) [41]. The randomization process was repeated 10000 times to obtain null distributions of the alpha and beta diversity estimates at each hierarchical level. The probabilities obtained from randomization tests were interpreted as $P$ values in the sense that a low $P$ value $(P<0.05)$ indicates that the observed diversity is significantly higher than that expected under the null model and a high $P$ value $(P>0.95)$ indicates that the observed diversity is significantly lower than that expected [42].

A 2-dimensional nonmetric multidimensional scaling (NMS) plot was obtained based on the Sorensen BrayCurtis similarity between all samples [43] to evaluate composition of zooplankton across reaches, pool/habitats, and seasons. The significance of differences was tested using the multiresponse permutation procedure (MRPP) [44]. To all MRPP analyses, the value of $\mathrm{A}$ is presented as a measure of the degree of homogeneity between groups compared to random expectation. Data were transformed by the arcsine square root [39]. Indicator species analysis [45] was used to determine which species discriminated the different spatial and temporal scales. The significance of the discriminating power (IV) was determined by the Monte Carlo test (1000 permutations). This analysis assigns an indicator value for each species, based on the degree to which they discriminate among groups. These groups are determined a priori and, in the present study, represent river reaches at each season. The indicator value ranges from zero (no indication) to 100 (perfect indication) of a species for a group. Perfect indication means that the presence of a species points to that particular group [46]. To assess how well environmental constraints across river reaches and seasons were correlated with the assemblages composition, a canonical correspondence analysis (CCA) was performed. The data matrix was centered and normalized and the correlations tested by the Monte Carlo test with 999 runs. The environmental variables used in the CCA were temperature, dissolved oxygen, transparency, $\mathrm{pH}$, and pool area. Density data were arcsine square root transformed and the environmental variables, except for $\mathrm{pH}$, were $\log _{10}(x+1)$ transformed $[39,47]$.

\section{Results}

Rainfall during the present study was highly variable, with most peaks and higher cumulative precipitation being 
recorded between April and June, whereas the dryer period was observed between July and November (Figure 2); as a consequence, surface water flow was observed only at the Cariri reach during the first sampling occasion (Table 1). Thus, river reach morphology varied regarding the presence and size of the temporary pools. During both wet and dry seasons, the Santana and Caraúbas reaches presented relatively large single pools of different sizes, whereas the Cariri reach presented two smaller pools of different sizes, during the dry season (Table 1).

River waters were neutral to slightly alkaline (range between 7.5 and 8.2 ) and well oxygenated (3.4 to $8.8 \mathrm{mg} / \mathrm{L}$ ). Conductivity was below $5 \mu \mathrm{S} / \mathrm{cm}$ at the Cariri and Santana reaches, whereas it remained above $900 \mu \mathrm{S} / \mathrm{cm}$ at the Caraúbas reach. Water temperature amplitude was low, ranging between 26 and $30.9^{\circ} \mathrm{C}$, and transparency relatively high, between 56 and $115 \mathrm{~cm}$. Sediment was composed mostly of sand and gravel, whereas the aquatic habitat was diverse with higher proportional contributions of aquatic macrophytes, marginal grass, algae, woody debris and leaf litter, and lower contributions of vegetal cover and submerged vegetation (Table 1).

The plankton fauna was composed of 37 species. Of these 28 were Rotifera, 5 were Cladocera, and 4 were Copepoda (nauplii of Copepoda were also recorded). Overall densities were low and only 8 taxa showed densities greater than 5 ind $\mathrm{m}^{-3}$. The ones with higher density were Brachionus havanaensis ( 317.23 ind $^{-3}$ ), Brachionus caudatus $\left(178.62\right.$ ind $\left.\mathrm{m}^{-3}\right)$, and Hexarthra mira (177.71 ind $\mathrm{m}^{-3}$ ) (Table 2). The most frequently observed taxa were Polyarthra dolicoptera and Copepoda nauplii, occuring on all study reaches and in both sampling occasions. Cladocera was the taxa with the lowest overall density, with higher values presented by Alonella granulata and Diaphanosoma spinulosum $\left(0.28\right.$ ind $\mathrm{m}^{-3}$ and 0.13 ind $\mathrm{m}^{-3}$, resp.). Copepoda with higher densities were the naupliar stages $\left(153.07 \mathrm{ind}^{-3}\right)$ and Mesocyclops longisetus $\left(2.5 \mathrm{ind}^{-3}\right)$ (Table 2).

Factorial ANOVA showed significant interaction in richness and density across reaches, habitats, and seasons (threeway ANOVA, $F_{R}=7.79$; d.f. $=4,36 ; P<0.001 ; F_{D}=7.24$; d.f. $=4,36 ; P<0.001$ ). Thus, we interpreted the next high-order terms of the ANOVA, which were the two-way interactions between habitat $*$ reach, habitat $*$ season, and reach $*$ season. These two-way interactions were significant for density (but not for richness) between habitat and river reach (three-way ANOVA, $F_{D}=4.60$; d.f. $=4,36 ; P=0.004$ ) and habitat and season (three-way ANOVA, $F_{D}=7.50$; d.f. $=2,36 ; P<0.002$ ). Analysis of simple main effects for these two-way interactions showed that habitat samples varied significantly for density only in the Cariri river reach (two-way ANOVA, $F_{D}=11.6$; d.f. $=2,36 ; P<0.001$ ) and during the wet season (two-way ANOVA, $F_{D}=12.3$; d.f. $=$ 2,36; $P<0.001)$.

The two-way interaction remaining to be interpreted was the interaction between river reach and season, which was significant for both richness and density (three-way ANOVA, $F_{R}=32.69$; d.f. $=2,36 ; P<0.001 ; F_{D}=53.41$; d.f. $=2,36$; $P<0.001)$. Multiple and pairwise comparisons showed that

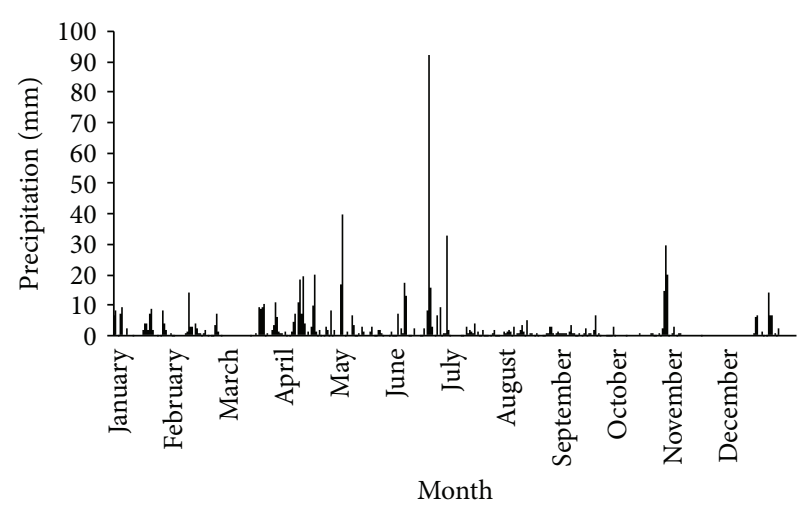

FIgURE 2: Precipitation at the São João do Cariri station from January to December 2010. Source: http://www.cptec.inpe.br/proclima/.

richness and density varied significantly across river reaches (Tukey tests $<0.04$ ) except for richness between Santana and Caraúbas during the dry season $(P=0.547)$ and between Cariri and Caraúbas during the wet season $(P=0.385)$ (Figure 3).

Partitioning of alpha and beta diversity components showed, in general, similar results for both wet and dry season collections (Figure 4 ). The partitioning of diversity showed that, for the sub-sample scale $(\alpha 1)$, diversity was lower than expected from the null model $(P>0.999)$ for both seasons, yet the mean number of taxa was similar between wet and dry seasons (6.78 and 7.37, resp.). The relative magnitude of the $\beta 1$ component (among sub-samples) was generally low and similar between seasons. Nevertheless, $\beta 1$ was higher than the expected from the null model $(P=0.034)$ in the wet season and lower in the dry season $(P=0.992)$. Values of the $\beta 2$ component (among habitats or pools) were higher than expected from individual-based randomization during the dry season $(P=0.002)$ and equal to expectation during the wet season $(P=0.101)$. This component represented 8 and 19\% (wet and dry season, resp.) of the total diversity of zooplankton. The $\beta 3$ component (between river reaches) presented higher diversity than that expected from the null model $(P<0.001)$ and represented $67 \%$ of the diversity during the wet season and $52 \%$ during the dry season.

Nonmetric multidimensional scaling (NMS) (Figure 5) showed clear segregation in the zooplankton community across the three study reaches (MRPP, Cariri/Caraúbas, $A=$ 0.22; $P=0.003$; Cariri/Santana, $A=0.34 ; P=0.0004$; Caraúbas/Santana, $A=0.29 ; P=0.0008)$ and between seasons within river reaches (MRPP, Cariri $A=0.43 ; P=$ 0.023; Santana, $A=0.43 ; P=0.022$; Caraúbas, $A=0.43 ; P=$ 0.022 ). Indicator species analysis (ISA) showed that the taxa that significantly contributed to the segregation between river reaches during the wet season were Polyarthra vulgaris (IV = 68.2; $P=0.01$, Cariri reach), Filinia longiseta (IV = 69.5; $P=0.02$, Caraúbas reach) and Brachionus caudatus (IV = 98.5; $P=0.01$, Santana reach) and during the dry season were Pompholyx sulcata (IV = 100; $P=0.01$ ) and Rotaria sp. (IV = 75.5; $P=0.02$ ) for the Cariri reach, Lecane leontina (IV = $100 ; P=0.01)$ and Macrothrix sp. (IV $=100 ; P=0.01)$ for the Caraúbas reach, and Brachionus havanaensis (IV = 99.7; 
TABLE 1: Environmental variables measured at the Paraiba River basin during the 2010 hydrological cycle.

\begin{tabular}{|c|c|c|c|c|c|c|}
\hline \multirow{2}{*}{$\begin{array}{l}\text { River reach } \\
\text { Season }\end{array}$} & \multicolumn{2}{|c|}{ Cariri } & \multicolumn{2}{|c|}{ Caraúbas } & \multicolumn{2}{|c|}{ Santana } \\
\hline & Wet $^{*}$ & Dry $^{* *}$ & Wet & Dry & Wet & Dry \\
\hline \multicolumn{7}{|l|}{ Water quality } \\
\hline $\mathrm{pH}$ & 7.8 & 7.6 & 7.9 & 7.5 & 8.2 & 7.6 \\
\hline Dissolved oxygen $(\mathrm{mg} / \mathrm{L})$ & 6.1 & 8.8 & 7.2 & 3.4 & 6.9 & 7.0 \\
\hline Conductivity $(\mu \mathrm{S} / \mathrm{cm})$ & 2.2 & 3.9 & 915.3 & 1092.3 & 2.8 & 4.7 \\
\hline Temperature $\left({ }^{\circ} \mathrm{C}\right)$ & 27.1 & 30.9 & 26.0 & 27.6 & 26.1 & 27.4 \\
\hline Water transparency $(\mathrm{cm})$ & 58.3 & 56.0 & 75.0 & 115.0 & 69.0 & 63.0 \\
\hline Water velocity $(\mathrm{m} / \mathrm{s})$ & 0.1 & 0 & 0 & 0 & 0 & 0 \\
\hline \multicolumn{7}{|l|}{ Morphometry } \\
\hline Average depth $(\mathrm{cm})$ & 44.2 & $61.3 / 62.0$ & 51.4 & 52.1 & 47.0 & 40.3 \\
\hline Average width (m) & 19.0 & $23.9 / 17.8$ & 9.3 & 10.3 & 65.1 & 63.7 \\
\hline Length (m) & n.a. & $19.9 / 13.7$ & 78.8 & 78.6 & 365.0 & 290.0 \\
\hline Total area $\left(\mathrm{m}^{2}\right)$ & n.a. & 464.0 & 750.0 & 832.0 & 23400.0 & 17200.0 \\
\hline Reach altitude (m) & 420.0 & 420.0 & 423.0 & 423.0 & 315.0 & 315.0 \\
\hline \multicolumn{7}{|l|}{ Substrate composition (\%) } \\
\hline Mud & 0 & 0.9 & 0 & 1.0 & 0.7 & 3.0 \\
\hline Sand & 78.3 & 90.4 & 98.8 & 99.5 & 89.5 & 83.8 \\
\hline Gravel & 21.6 & 8.3 & 1.3 & 0 & 9.2 & 13.3 \\
\hline Cobbles & 0 & 0.4 & 0 & 0 & 0.7 & 0 \\
\hline \multicolumn{7}{|l|}{ Habitat structure (\%) } \\
\hline Macrophytes & 0.1 & 9.0 & 15.0 & 50.0 & 22.4 & 27.5 \\
\hline Grass & 0 & 0 & 16.3 & 27.5 & 2.0 & 3.8 \\
\hline Submerged vegetation & 3.8 & 0 & 2.0 & 0 & 0.2 & 0 \\
\hline Vegetal cover & 5.0 & 6.3 & 0.3 & 0 & 0 & 1.3 \\
\hline Leaf litter & 5.0 & 2.0 & 0.3 & 0 & 0 & 0 \\
\hline Algae & 2.5 & 2.0 & 8.8 & 5.0 & 5.4 & 3.8 \\
\hline Woody debris & 4.0 & 8.0 & 1.3 & 0 & 2.5 & 1.3 \\
\hline
\end{tabular}

${ }^{*}$ Reach with surface water flow. ${ }^{* *}$ Two pools were surveyed.

$P=0.01)$, Keratella valga $(\mathrm{IV}=98.9 ; P=0.01)$, Asplanchna sieboldi $(\mathrm{IV}=100 ; P=0.007)$, and Notodiaptomus sp. $(\mathrm{IV}=100 ; P=0.007)$ for the Santana reach.

The first three axes of CCA explained $70.8 \%$ of the variation in zooplankton composition across river reaches, with a total variance (inertia) of 2.53. Most of the explained variations, based on the correlations between the environmental variables and the CCA axes, were explained by the first axis (27.2\%), but the axes 2 and 3 were also important, explaining a substantial part of the variation in the data matrix (Table 3 ). The correlation between the zooplankton composition and the environmental variables was significant as shown by the Monte Carlo test for the eigenvalues and the speciesenvironment correlations $(P=0.009)$ (Table 3, Figure 6). According to the interset correlations between the environmental variables and the CCA axes, the most important variables explaining the zooplankton composition were $\mathrm{pH}$, dissolved oxygen, and water transparency (Table 3, Figure 6).

\section{Discussion}

Richness and composition of zooplankton observed in the present study are in accordance with other studies developed in the semiarid region of Brazil [11, 27, 48, 49] and elsewhere
[50]. During the present study, Rotifera dominated in terms of richness and density. This has been reported for other systems [51] and is generally attributed to their high fecundity, parthenogenic reproduction, and high growth rates [15]. These characteristics, in association with the generalist feeding habit, make the Rotifera a typically r-strategist and opportunist group [52]. According to Medeiros et al. [11] these strategies are favored by the highly variable nature of the intermittent streams.

Among the Rotifera registered in the present study, Brachionidae and Lecanidae were the most representative in number of species (see also [18]). Brachionidae species are usually associated with the plankton whereas Lecanidae is mostly littoraneous, being associated with the benthos and periphyton or macrophyte stands [49]. The nonspecialized feeding of these taxa as well as the presence of a diverse array of littoral underwater structures and of aquatic macrophytes [16] associated with the low flows at the time of collection and the subsequent water retention is likely to have enhanced the richness of these taxa [53]. On the other hand, lower richness and density of Cladocera and Copepoda is explained by their more selective nature in relation to food and environmental changes. As reported by Walz and Welker [54] and Vieira et al. [18] these taxa tend to disappear or 
TABLE 2: Density (ind $\mathrm{m}^{-3}$ ) of zooplankton species at the Paraiba River basin during the 2010 hydrological cycle.

\begin{tabular}{|c|c|c|c|c|c|c|}
\hline \multirow{2}{*}{ 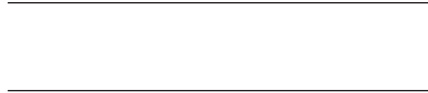 } & \multicolumn{2}{|c|}{ Cariri } & \multicolumn{2}{|c|}{ Caraúbas } & \multicolumn{2}{|c|}{ Santana } \\
\hline & Wet & Dry & Wet & Dry & Wet & Dry \\
\hline \multicolumn{7}{|l|}{ Rotifera } \\
\hline \multicolumn{7}{|l|}{ Asplanchnidae } \\
\hline Asplanchna sieboldi & - & - & - & - & - & 1.45 \\
\hline \multicolumn{7}{|l|}{ Brachionidae } \\
\hline Brachionus angularis & - & 12.34 & - & 0.08 & 31.45 & 104.57 \\
\hline B. havanaesis & - & 0.01 & - & - & 317.22 & - \\
\hline B. calyciflorus & 0.09 & 2.67 & - & 0.13 & 0.97 & 10.83 \\
\hline B. caudatus & 0.03 & - & 0.03 & - & 178.57 & - \\
\hline B. plicatilis & - & 0.08 & - & - & 1.41 & 0.44 \\
\hline B. quadridentatus & - & - & - & 0.01 & 0.52 & - \\
\hline B. urceolaris & - & - & - & - & - & 0.05 \\
\hline Keratella cochlearis & - & - & - & - & - & 0.03 \\
\hline K. valga & 0.01 & - & - & - & 31.24 & - \\
\hline Plationus patulus & - & - & 0.28 & 0.25 & - & - \\
\hline \multicolumn{7}{|l|}{ Euchlanidae } \\
\hline Euchlanis dilatata & - & - & - & 0.03 & - & - \\
\hline \multicolumn{7}{|l|}{ Mytilinidae } \\
\hline Mytilina ventralis & - & 0.01 & - & 0.01 & - & 0.04 \\
\hline \multicolumn{7}{|l|}{ Hexarthridae } \\
\hline Hexarthra mira & - & - & - & - & 100.34 & 55.37 \\
\hline \multicolumn{7}{|l|}{ Synchaetidae } \\
\hline Polyarthra dolicoptera & 0.10 & 0.01 & 2.15 & 0.09 & 0.03 & 9.86 \\
\hline P. vulgaris & 3.75 & 0.06 & 0.34 & 0.24 & 0.04 & - \\
\hline \multicolumn{7}{|l|}{ Lecanidae } \\
\hline Lecane bulla & 0.03 & 0.04 & - & 0.01 & 0.11 & - \\
\hline L. hamata & - & - & - & 0.16 & - & - \\
\hline L. hastata & - & - & 0.01 & 0.10 & - & 0.01 \\
\hline L. leontina & - & - & - & 0.09 & - & - \\
\hline L. luna & - & - & - & 0.03 & - & - \\
\hline L. lunaris & - & - & - & 0.03 & 0.08 & - \\
\hline \multicolumn{7}{|l|}{ Colurellidae } \\
\hline Lepadella sp. & - & - & - & 0.01 & - & - \\
\hline \multicolumn{7}{|l|}{ Filiniidae } \\
\hline Filinia longiseta & - & - & 0.25 & - & 0.01 & 0.06 \\
\hline \multicolumn{7}{|l|}{ Trichocercidae } \\
\hline Trichocerca sp. & - & 0.01 & 0.04 & - & 0.01 & - \\
\hline \multicolumn{7}{|l|}{ Testudinellidae } \\
\hline Pompholyx sulcata & - & 3.15 & - & - & - & - \\
\hline Testudinella patina & - & - & - & - & 0.14 & - \\
\hline \multicolumn{7}{|l|}{ Philodinidae } \\
\hline Rotaria sp. & - & 1.02 & 0.01 & 0.05 & 0.05 & - \\
\hline \multicolumn{7}{|l|}{ Cladocera } \\
\hline \multicolumn{7}{|l|}{ Chydoridae } \\
\hline Alonella granulata & - & - & - & 0.05 & 0.23 & - \\
\hline Chydorus eurynotus & - & 0.01 & - & 0.03 & - & - \\
\hline \multicolumn{7}{|l|}{ Daphniidae } \\
\hline Ceriodaphnia cornuta & - & - & - & 0.09 & - & 0.03 \\
\hline Diaphanosoma spinulosum & - & - & - & 0.10 & - & 0.03 \\
\hline Macrothricidae & & & & & & \\
\hline Macrothrix sp. & - & - & - & 0.05 & - & - \\
\hline
\end{tabular}


TABLE 2: Continued.

\begin{tabular}{lcccccc}
\hline & \multicolumn{2}{c}{ Cariri } & \multicolumn{2}{c}{ Caraúbas } & \multicolumn{2}{c}{ Santana } \\
& Wet & Dry & Wet & Dry & Wet & Dry \\
\hline $\begin{array}{l}\text { Copepoda } \\
\quad \text { Nauplii }\end{array}$ & 4.50 & 1.92 & 6.59 & 4.66 & 76.26 & 59.13 \\
$\quad \begin{array}{l}\text { Cyclopoida } \\
\quad \text { Mesocyclops longisetus }\end{array}$ & 0.09 & 0.03 & - & 0.05 & 2.11 & 0.14 \\
$\quad \begin{array}{l}\text { Paracyclops sp. } \\
\quad \text { Thermocyclops sp. }\end{array}$ & - & 0.01 & - & 0.03 & 0.57 & - \\
$\quad$ Calanoida & - & - & - & - & 0.09 & - \\
$\quad$ Notodiaptomus sp. & - & - & - & - & - & 0.06 \\
\hline Total & 8.59 & 21.38 & 9.70 & 6.35 & 741.43 & 242.09 \\
\hline
\end{tabular}

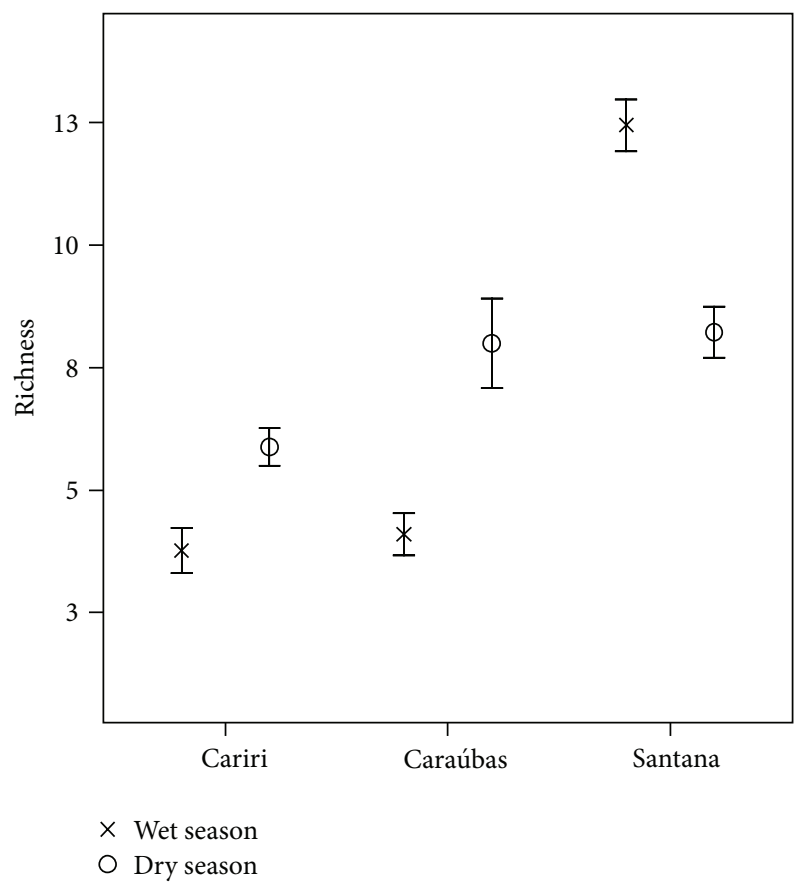

(a)

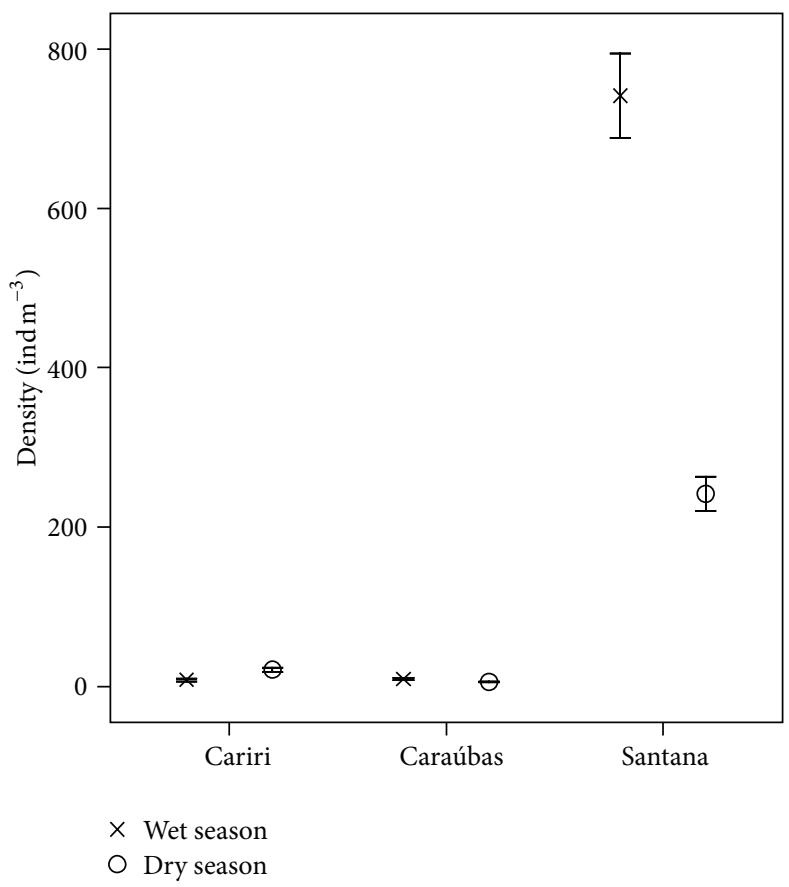

(b)

FIgUre 3: Average \pm SE of richness and density of zooplankton at the Paraiba River basin during the 2010 hydrological cycle.

occur in very low abundance as the dry season progresses into harsh conditions and reappear when conditions become appropriate [55]. The higher densities of naupliar stages of Copepoda in the present study are the result of their ability to rapidly colonize temporary environments [56] associated with their high capacity to survive during recurrent events like the dry season in intermittent rivers [57].

During the present study, the river reaches were characterized by low to total absence of water flow, leading to the predominance of pools as the habitat available for the plankton fauna. The hydrological variation and dry periods have been reported to change the structure of the communities of zooplankton (see $[11,18]$ ), where species with strategies to cope with the harsh and variable conditions during the dry season are selected among a larger possible array of species. Such environmental variability would lead to a spatial segregation, as the hydrological cycle progresses into specific habitats and communities [58], and has been proposed to create a mosaic of local habitats at the pool scale and at the microhabitat within pool level in Brazilian semiarid rivers [5]. Thus, biological communities would be expected to assume different structures and composition along the river in accordance with the environmental heterogeneity. In the present study, analysis of variance supports that claim by showing significantly different richness across river reaches and habitats/pools and strong interaction with seasons. These interactions come, mostly, from the fact that richness was higher at the Santana reach during the wet period and density was higher at that reach during both seasons. Density and richness results for the other reaches were less conclusive, showing significant and nonsignificant variations across spatial and temporal scales, and only partially support the above argumentation. In particular, the significant variation observed in density across habitat samples in the Cariri reach 


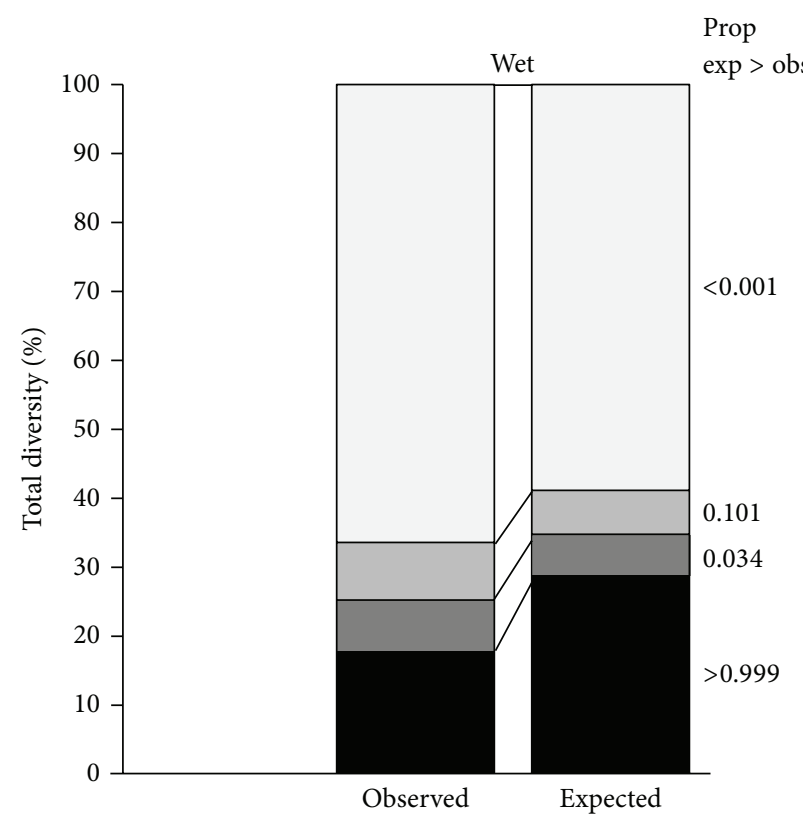

$\square \beta 3$
$\square \beta 2$
$\square \beta 1$
$\alpha 1$

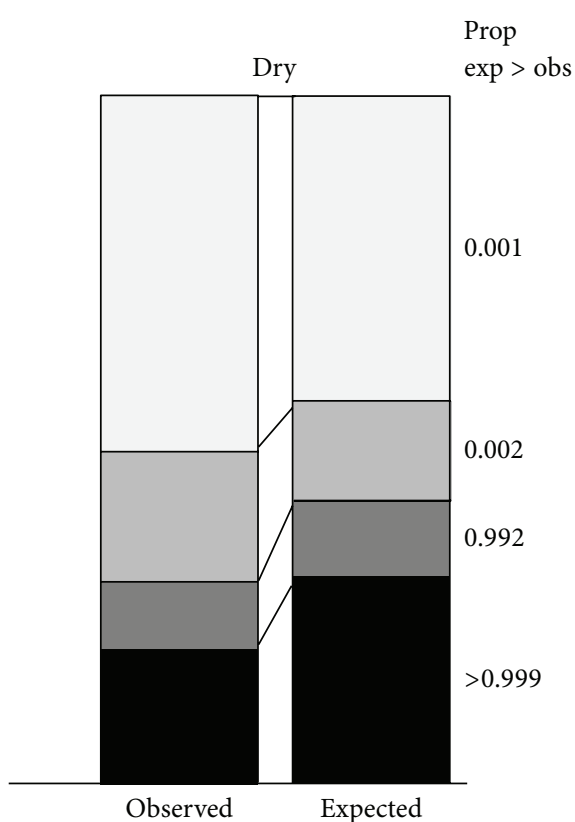

$\square \beta 3$
$\square \beta 2$
$\square \beta 1$
$\square 1$

(a)

(b)

FIGURE 4: Observed and expected diversity, partitioned into one alpha and three beta components, expressed as percent of total species richness. Numbers indicate the proportion of randomized samples containing more species than the observed sample for each partition. $\alpha 1$ : subsample species richness, $\beta 1$ : beta diversity among sub-samples; $\beta 2$ : beta diversity among pools or habitats within pool, and $\beta 3$ : beta diversity among river reaches.

TABLE 3: Summary of axes for the canonical correspondence analysis of the zooplankton fauna and the environmental variables in the Paraiba River basin during the 2010 hydrological cycle.

\begin{tabular}{lccc}
\hline & \multicolumn{3}{c}{ CCA axes } \\
& 1 & 2 & 3 \\
\hline Eigenvalues & 0.687 & 0.615 & 0.487 \\
$\quad$ Monte Carlo test & 0.009 & & \\
\% variance explained & 27.2 & 24.3 & 19.3 \\
Pearson's correlations & 1.000 & 1.000 & 1.000 \\
Interset correlations & & & \\
$\quad$ Temperature & 0.388 & -0.237 & 0.633 \\
$\quad$ D. O. (mg/L) & 0.816 & -0.405 & 0.385 \\
$\quad$ Water transparency (cm) & 0.794 & 0.479 & -0.355 \\
$\quad$ pH & 0.862 & 0.404 & -0.098 \\
$\quad$ Area (m ${ }^{2}$ ) & 0.728 & -0.306 & -0.597 \\
Species-environment correlations & 1.000 & 1.000 & 1.000 \\
Monte Carlo test & 0.009 & & \\
\hline
\end{tabular}

is likely the result of flooding during the wet season which decreased zooplankton numbers and enhanced intrareach variability.
The Santana reach was an important source of univariate (richness and density) variation across the study spatial and temporal scales, showing overall higher densities and the most abundant species. Furthermore, density and richness tended to be higher in the dry season at the Cariri and Caraúbas reaches, but not at the Santana reach. Higher density and richness during the dry season in intermittent streams has also been reported in other studies and was associated with increased concentration of nutrients at shrinking pools and higher water residence time [11, 15]. It is likely that the opposite relationship observed in the Santana reach is related with the greater human impact that this reach suffers in comparison with the others, since it receives organic inputs from local human communities and from an adjacent intermittent tributary that receives waste water from a nearby town. This probably resulted in the observed high abundance of species that are indicative of eutrophic environments such as the genus Brachionus [59] and specially Brachionus angularis and B. havanaensis [60].

Analysis of diversity partition provided additional support for the importance of local habitats/pools to the regional diversity, since the observed $\beta$ was higher than the expected for both local habitats $(\beta 2)$ and the river reaches $(\beta 3)$. It also provides evidence that wet and dry periods play an important role in this partition, particularly at the lower 


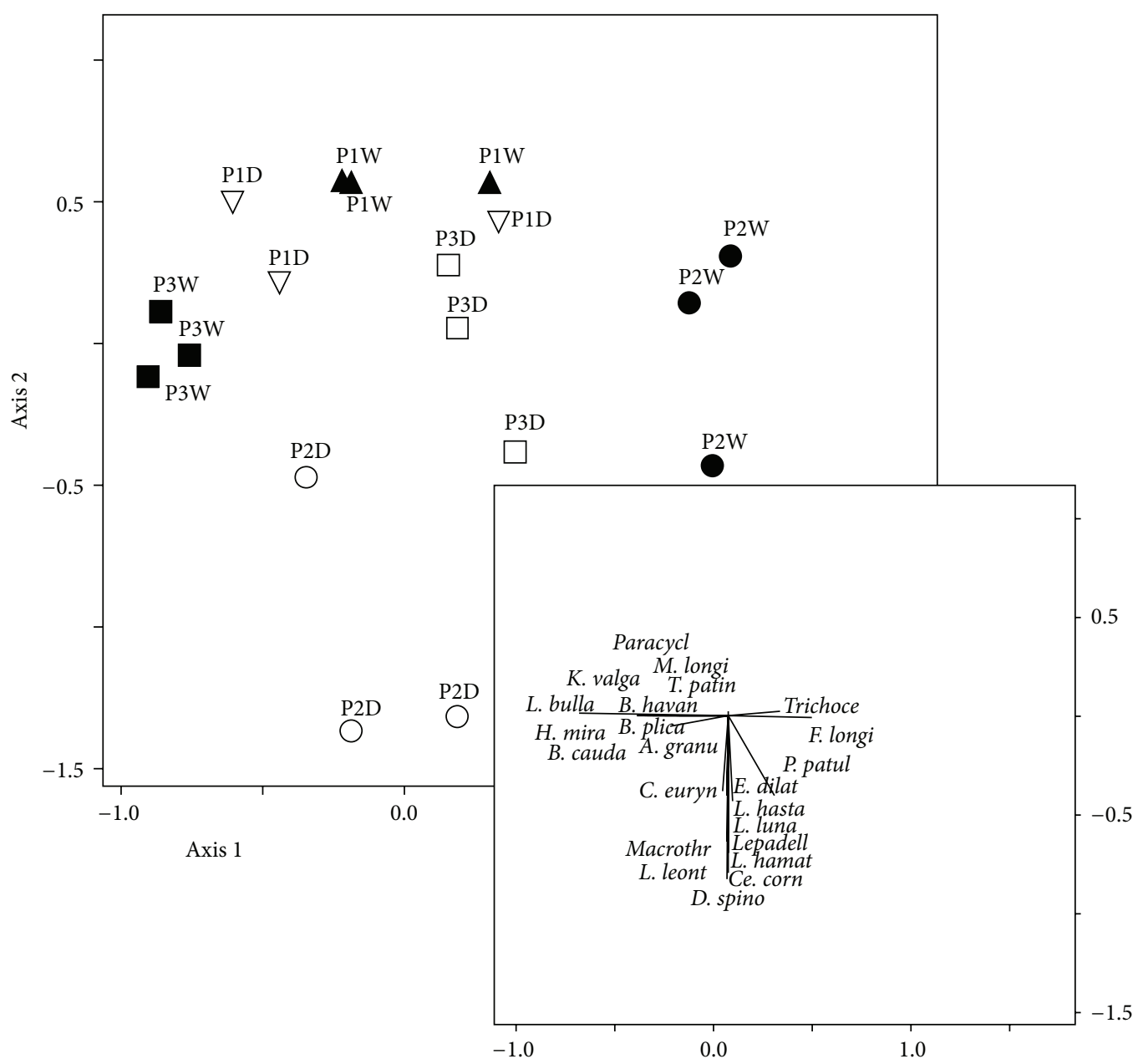

FIGURE 5: NMS results for zooplankton composition across the study reaches $(\mathrm{P} 1=$ Cariri, $\mathrm{P} 2=$ Caraúbas, and P3 = Barra de Santana $)$ in the Paraiba River basin during the wet $(\mathrm{W})$ and dry $(\mathrm{D})$ seasons. Vectors (inset box) show taxa correlated $\left(R^{2}>0.2\right)$ with samples in ordination space. The direction and length of vectors indicate strength of correlation.

scales of diversity $(\beta 2)$, as shown by the higher observed and expected diversity during the dry period compared to the wet period. The importance of flooding on zooplankton composition has been recognized for intermittent aquatic environments in semiarid Brazil [18, 27]. In this study, we further support those views and highlight that the dry season or the absence of water flow enhances diversity by segregating the fauna composition among pools and therefore increasing $\beta$ diversity at the pool/habitat scale (see also [11]). At larger spatial scales, in the present study at the river reach scale, the wet season has greater importance to $\beta$ diversity. That is the result of the susceptibility of the zooplankton to water flow, which increases the potential for different assemblages at different reaches. In this context, the effects of varying magnitude, intensity, and frequency of flooding across river reaches remain untested.

At the larger spatial scale, ordination showed different compositions of the zooplankton fauna across river reaches and that, despite this spatial segregation, a few species of
Brachionidae and Lecanidae dominated. The dominance of specific groups of zooplankton across segregated assemblages has been reported for Brazilian semiarid aquatic systems [11]. This has been linked to species' responses to the hydrological disturbances which can create conditions that select species from a common larger pool of species that is broken into more specific assemblages at local scales [61]. The $\alpha 1$ observed for both study seasons was low, and the $\beta 2$ diversity for the wet season represented a smaller fraction of the total diversity compared with the dry season. These results indicate not only higher intraspecific aggregation at the fine scales [62], but also that the habitat/pool diversity is more aggregated during the wet period. In theory this could be explained by the increased proportion of ecological interactions of conspecifics (intraspecific aggregation) in comparison with interspecific interactions, which reduces competitive exclusion and enhances diversity [63]. In the present study, this may be associated with physical and chemical changes in the water and most likely pool area and/or microhabitat diversity. 


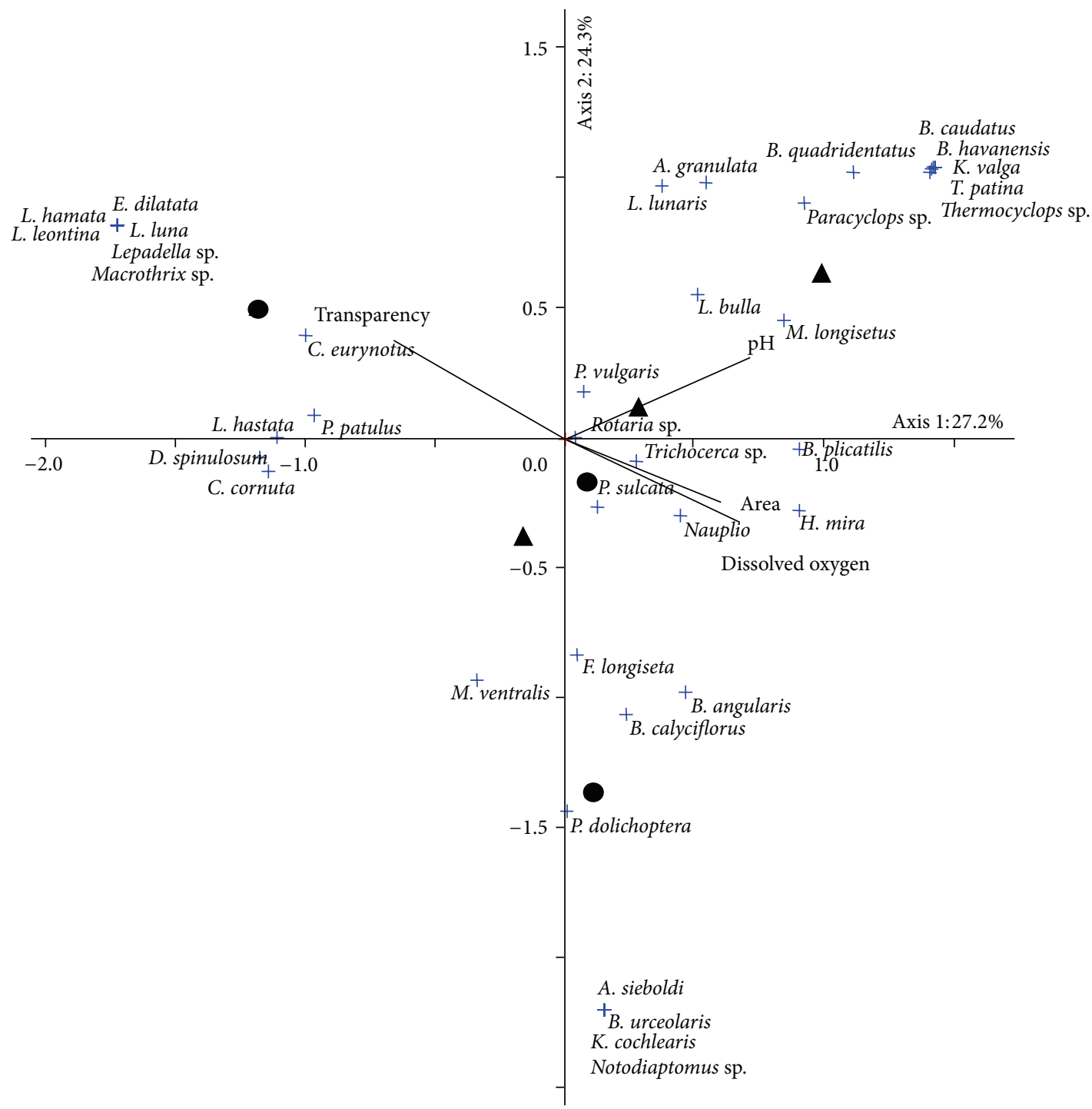

A Wet season

Dry season

FIGURE 6: Biplot of CCA showing the composition of zooplankton in the sampling sites and seasons and the explanatory environmental variables defined by CCA.

Other physical and chemical factors, such as discharge, water temperature, $\mathrm{pH}$, dissolved oxygen, and habitat complexity, have been shown to affect the zooplankton community [18].

Canonical correspondence analysis showed that a significant portion of the zooplankton distribution and composition was explained by the environmental variables. Brachionus caudatus, B. havanaensis, B. quadridentatus, Keratella valga, Lecane bulla, L. lunaris, Polyarthra vulgaris, Testudinella patina, Rotaria sp., Alonella granulata, Mesocyclops longisetus, Paracyclops sp. and Thermocyclops sp., were associated with habitats with higher $\mathrm{pH}$, whereas Plationus patulus, Lecane hastata, L. leontina, L. luna, Euchlanis dilatata, Lepadella sp., Ceriodaphnia cornuta, Diaphanosoma spinulosum, Chydorus eurynotus, and Macrothrix sp., were more abundant in habitats with greater water transparency. Pool area and dissolved oxygen explained substantial part in the distribution and abundance of Trichocerca sp., Brachionus angularis, B. calyciflorus, B. plicatilis, B. urceolaris, Hexarthra mira, Pompholyx sulcata, Filinia longiseta, Polyarthra dolicoptera, Asplanchna sieboldi, Keratella cochlearis, Notodiaptomus sp., and naupliar stages of Copepoda. The effects of pool area and the other environmental variables have been viewed as important to species' richness [64], even though the effects of these variables are difficult to be evaluated separately. Hessen et al. [65], for instance, pointed out that primary production and predation have greater effect on the zooplankton community than external factors such as area and geographic limits. Furthermore, physical and chemical variables in dryland 
rivers (e.g., conductivity and water transparency) have been reported to be associated with larger scale or geomorphologic processes [66] or with other variables operating at lower spatial scales (e.g., dissolved oxygen) [5].

\section{Conclusions}

This study showed that the zooplankton presents a spatially segregated pattern of species composition across river reaches and that at low spatial scales (among pools or different habitats within pools) the diversity of species is likely to be affected by temporal changes in physical and chemical characteristics. As a consequence of the drying of pool habitats, the spatial heterogeneity within the study river reaches has the potential to increase local $\beta$ diversity during the dry season by creating patchier assemblages. This spatial segregation in community composition and the patterns of partition of the diversity across the spatial scales leads to a higher total diversity in intermittent streams, compared to less variable environments.

\section{Acknowledgments}

The authors are grateful to Professor. Maria Cristina Crispim (Universidade Federal da Paraíba) for confirming the identification of zooplankton. Thais Melo is grateful to the "Programa de Iniciação Científica UEPB/CNPq" for the scholarship granted (PIBIC/CNPq/UEPB 2010-2011). Elvio Medeiros holds a Brazilian Research Council (CNPq) Research Productivity Grant (312028/2012-1). This research was supported by funds from Edital 01/2008 PRPGP/UEPB - PROPESQ 007/2008.

\section{References}

[1] L. Maltchik and M. Florin, "Perspectives of hydrological disturbance as the driving force of Brazilian semiarid stream ecosystems," Acta Limnologica Brasiliensia, vol. 14, no. 3, pp. 3541, 2002.

[2] W. T. Liu and R. I. Negrón Juárez, "ENSO drought onset prediction in northeast Brazil using NDVI," International Journal of Remote Sensing, vol. 22, no. 17, pp. 3483-3501, 2001.

[3] E. R. Steffan, "Hidrografia," in Região Nordeste. Geografia Do Brasil, IBGE, Ed., pp. 111-133, SERGRAF-IBGE, Rio de Janeiro, Brazil, 1977.

[4] L. Maltchik and E. S. F. Medeiros, "Conservation importance of semi-arid streams in north-eastern Brazil: implications of hydrological disturbance and species diversity," Aquatic Conservation: Marine and Freshwater Ecosystems, vol. 16, no. 7, pp. 665677, 2006

[5] E. S. F. Medeiros, M. J. Silva, and R. T. C. Ramos, "Application of catchment- and local-scale variables for aquatic habitat characterization and assessment in the Brazilian semi-arid region," Neotropical Biology and Conservation, vol. 3, no. 1, pp. 13-20, 2008.

[6] E. H. Stanley, S. G. Fisher, and N. B. Grimm, "Ecosystem expansion and contraction in streams: desert streams vary in both space and time and fluctuate dramatically in size," BioScience, vol. 47, no. 7, pp. 427-435, 1997.
[7] S. G. Fisher, N. B. Grimm, E. Martí, and R. Gómez, "Hierarchy, spatial configuration, and nutrient cycling in a desert stream," Austral Ecology, vol. 23, no. 1, pp. 41-52, 1998.

[8] M. C. Crispim and G. T. P. Freitas, "Seasonal effects on zooplanktonic community in a temporary lagoon of northeast Brazil," Acta Limnologica Brasiliensia, vol. 17, no. 4, pp. 385-393, 2005.

[9] E. S. F. Medeiros and L. Maltchik, "Diversity and stability of fishes (Teleostei) in a temporary river of the Brazilian semiarid region," Iheringia, no. 90, pp. 157-166, 2001.

[10] L. De Meester, S. Declerck, R. Stoks et al., "Ponds and pools as model systems in conservation biology, ecology and evolutionary biology," Aquatic Conservation, vol. 15, no. 6, pp. 715-725, 2005.

[11] E. S. F. Medeiros, M. P. Noia, L. C. Antunes, and T. X. Melo, "Zooplankton composition in aquatic systems of semi-arid Brazil: spatial variation and implications of water management," Pan-American Journal of Aquatic Sciences, vol. 6, pp. 290-302, 2011.

[12] D. G. Jenkins and A. L. Buikema Jr., "Do similar communities develop in similar sites? A test with zooplankton structure and function," Ecological Monographs, vol. 68, no. 3, pp. 421-443, 1998.

[13] C. E. Cáceres and D. A. Soluk, "Blowing in the wind: a field test of overland dispersal and colonization by aquatic invertebrates," Oecologia, vol. 131, no. 3, pp. 402-408, 2002.

[14] J. L. Brooks and S. I. Dodson, "Predation, body size, and composition of plankton," Science, vol. 150, no. 3692, pp. 28-35, 1965.

[15] R. Pourriot, C. Rougier, and A. Miquelis, "Origin and development of river zooplankton: example of the Marne," Hydrobiologia, vol. 345, no. 2-3, pp. 143-148, 1997.

[16] J. H. Stansfield, M. R. Perrow, L. D. Tench, A. J. D. Jowitt, and A. A. L. Taylor, "Submerged macrophytes as refuges for grazing Cladocera against fish predation: observations on seasonal changes in relation to macrophyte cover and predation pressure," Hydrobiologia, vol. 342-343, pp. 229-240, 1997.

[17] M. Seminara, D. Vagaggini, and F. G. Margaritora, "Differential responses of zooplankton assemblages to environmental variation in temporary and permanent ponds: zooplankton of temporary and permanent ponds," Aquatic Ecology, vol. 42, no. 1, pp. 129-140, 2008.

[18] A. C. B. Vieira, L. L. Ribeiro, D. P. N. Santos, and M. C. Crispim, "Correlation between the zooplanktonic community and environmental variables in a reservoir from the Northeastern semiarid," Acta Limnologica Brasiliensia, vol. 21, no. 3, pp. 349-358, 2009.

[19] W. Sousa, J. L. Attayde, E. D. S. Rocha, and E. M. EskinaziSant'Anna, "The response of zooplankton assemblages to variations in the water quality of four man-made lakes in semi-arid northeastern Brazil," Journal of Plankton Research, vol. 30, no. 6, pp. 699-708, 2008.

[20] S. Tavernini, "Seasonal and inter-annual zooplankton dynamics in temporary pools with different hydroperiods," Limnologica, vol. 38, no. 1, pp. 63-75, 2008.

[21] K. M. Jenkins and A. J. Boulton, "Connectivity in a dryland river: short-term aquatic microinvertebrate recruitment following floodplain inundation," Ecology, vol. 84, no. 10, pp. 27082723, 2003.

[22] R. L. Farias, L. K. Carvalho, and E. S. F. Medeiros, "Distribution of Chironomidae in a semiarid intermittent river of Brazil," Neotropical Entomology, vol. 41, pp. 450-460, 2012. 
[23] L. G. Rocha, E. S. F. Medeiros, and H. T. A. Andrade, "Influence of flow variability on macroinvertebrate assemblages in an intermittent stream of semi-arid Brazil," Journal of Arid Environments, vol. 85, pp. 33-40, 2012.

[24] C. A. Frissell, W. J. Liss, C. E. Warren, and M. D. Hurley, "A hierarchical framework for stream habitat classification: viewing streams in a watershed context," Environmental Management, vol. 10, no. 2, pp. 199-214, 1986.

[25] C. M. Pringle, C. M. Pringle, R. J. Naiman et al., "Patch dynamics in lotic systems: the stream as a mosaic," Journal of the North American Benthological Society, vol. 7, pp. 503-524, 1988.

[26] M. C. Thoms, P. J. Beyer, and K. H. Rogers, "Variability, complexity and diversity - the geomorphology of river ecosystems in dryland regions," in Changeable, Changed, Changing: The Ecology of Desert Rivers, R. T. Kingsford, Ed., p. 368, Cambridge University Press, Cambridge, UK, 2004.

[27] N. R. Simões, S. L. Sonoda, and S. M. M. S. Ribeiro, "Spatial and seasonal variation of microcrustaceans (Cladocera and Copepoda) in intermittent rivers in the Jequiezinho River Hydrographic Basin, in the Neotropical semiarid," Acta Limnologica Brasiliensia, vol. 20, no. 3, pp. 197-204, 2008.

[28] E. S. F. Medeiros and A. H. Arthington, "Allochthonous and autochthonous carbon sources for fish in floodplain lagoons of an Australian dryland river," Environmental Biology of Fishes, vol. 90, no. 1, pp. 1-17, 2011.

[29] AESA, "Agência Executiva de Gestão das Águas do Estado da Paraíba. Disponível em," Paraíba, Brasil, 2012, http://www.aesa .pb.gov.br/.

[30] I. R. Leal, M. Tabarelli, and J. M. C. Silva, Eds., Ecologia e Conservação da Caatinga, EDUFPE, Recife, Brazil, 2nd edition, 2005.

[31] M. C. Peel, B. L. Finlayson, and T. A. McMahon, "Updated world map of the Köppen-Geiger climate classification," Hydrology and Earth System Sciences, vol. 11, no. 5, pp. 1633-1644, 2007.

[32] SUDENE, Dados Pluviométricos mensais do nordeste. Superintendência do Desenvolvimento do Nordeste, Recife, Brazil, 1990.

[33] J. M. C. Silva, M. Tabarelli, M. Fonseca, and L. Lins, Eds., Biodiversidade da Caatinga: áreas e ações prioritárias para a conservação, Ministério do Meio Ambiente/Universidade Federal de Pernanbuco, Brasília, DF, Brazil, 2003.

[34] J. F. Haney and D. J. Hall, "Sugar-coated Daphnia: a preservation technique for Cladocerans," Limnology and Oceanography, vol. 18, no. 2, pp. 331-333, 1973.

[35] L. M. A. Elmoor-Loureiro, Manual de identificação de cladóceros límnicos do Brasil, Editora Universa, Brasilia, DF, Brazil, 1997.

[36] E. Suárez, J. W. Reid, T. M. Ilige et al., Catálogo de los copépodos (Crustácea) continentales de la península de Yucatán, México, ECOSUR/CONABIO, Mexico City, Mexico, 1996.

[37] H. Segers, "Annotated checklist of the rotifers (Phylum Rotifera), with notes on nomenclature, taxonomy and distribution," Zootaxa, no. 1564, pp. 1-104, 2007.

[38] P. S. Maitland, Field Studies: Sampling in Freshwaters, in Biology of Fresh Waters, Blackie, Glasgow, UK, 1990.

[39] R. R. Sokal and F. J. Rohlf, Biometry: The Principles and Practice of Statistics in Biological Research, W.H. Freeman, San Francisco, Calif, USA, 1969.

[40] J. A. Veech and T. O. Crist, "PARTITION: software for hierarchical partitioning of species diversity, version 3.0," 2009, http://www.users.muohio.edu/cristto/partition.htm.

[41] T. O. Crist, J. A. Veech, J. C. Gering, and K. S. Summerville, "Partitioning species diversity across landscapes and regions: a hierarchical analysis of $\alpha, \beta$, and $\gamma$ diversity," American Naturalist, vol. 162, no. 6, pp. 734-743, 2003.

[42] J. A. Veech and T. O. Crist, "PARTITION 3. 0 user's manual," unpublished document, 2009.

[43] B. McCune and J. B. Grace, Analysis of Ecological Communities, Gleneden Beach, Ore, USA, MjM Software Design, 2002.

[44] M. E. Biondini, C. D. Bonham, and E. F. Redente, "Secondary successional patterns in a sagebrush (Artemisia tridentata) community as they relate to soil disturbance and soil biological activity," Vegetatio, vol. 60, no. 1, pp. 25-36, 1985.

[45] M. Dufrêne and P. Legendre, "Species assemblages and indicator species: the need for a flexible asymmetrical approach," Ecological Monographs, vol. 67, no. 3, pp. 345-366, 1997.

[46] B. McCune and M. J. Mefford, PC-ORD. Multivariate Analysis of Ecological Data. Version 4.27, MjM Software Design, Gleneden Beach, Ore, USA, 1999.

[47] L. Maltchik, L. E. K. Lanés, C. Stenert, and E. S. F. Medeiros, "Species-area relationship and environmental predictors of fish communities in coastal freshwater wetlands of southern Brazil," Environmental Biology of Fishes, vol. 88, no. 1, pp. 25-35, 2010.

[48] M. C. Crispim and T. Watanabe, "Caracterização Limnológica das Bacias doadoras e receptoras de águas do Rio São Francisco:1-Zooplâncton," Acta Limnologica Brasiliensia, vol. 12, no. 2, pp. 93-103, 2000.

[49] V. L. S. Almeida, M. E. L. de Larrazábal, A. D. N. Moura, and M. de Melo Júnior, "Rotifera das zonas limnética e litorânea do reservatório de Tapacurá, Pernambuco, Brasil," Iheringia, vol. 96, no. 4, pp. 445-451, 2006.

[50] K. Fahd, L. Serrano, and J. Toja, "Crustacean and rotifer composition of temporary ponds in the Doñana National Park (SW Spain) during floods," Hydrobiologia, vol. 436, pp. 41-49, 2000.

[51] J. Green, "Diversity and dominance in planktonic rotifers," Hydrobiologia, vol. 255-256, no. 1, pp. 345-352, 1993.

[52] J. D. Allan, "Life history patterns in zooplankton," American Naturalist, vol. 110, no. 971, pp. 165-176, 1976.

[53] K. G. Porter, J. D. Orcutt Jr., and J. Gerritsen, "Functional response and fitness in a generalist filter feeder Daphnia magna ( Cladocera: Crustacea)," Ecology, vol. 64, no. 4, pp. 735-742, 1983.

[54] N. Walz and M. Welker, "Plankton development in a rapidly flushed lake in the River Spree system (Neuendorfer See, Northeast Germany)," Journal of Plankton Research, vol. 20, no. 11, pp. 2071-2087, 1998.

[55] M. C. Crispim and T. Watanabe, "What can dry reservoir sediments in a semi-arid region in Brazil tell us about cladocera?" Hydrobiologia, vol. 442, no. 1-3, pp. 101-105, 2001.

[56] D. Frisch and A. J. Green, "Copepods come in first: rapid colonization of new temporary ponds," Fundamental and Applied Limnology, vol. 168, no. 4, pp. 289-297, 2007.

[57] G. A. Cole, "Contrasts among calanoid copepods from permanent and temporary ponds in Arizona," American Midland Naturalist, vol. 76, no. 2, pp. 351-368, 1966.

[58] F. Sheldon and K. F. Walker, "Spatial distribution of littoral invertebrates in the lower Murray-Darling River system, Australia," Marine and Freshwater Research, vol. 49, no. 2, pp. 171182, 1998.

[59] K. E. Esteves and S. Sendacz, "Relações entre a biomassa do zooplâncton e o estado trófico de reservatórios do estado de São Paulo," Acta Limnologica Brasiliensia, vol. 2, no. 1, pp. 587-604, 1988. 
[60] M. Serafim-Júnior, G. Perbiche-Neves, L. de Brito, A. R. Ghidini, and S. M. C. Casanova, "Variação espaço-temporal de Rotifera em um reservatório eutrofizado no sul do Brasil," Iheringia, vol. 100, no. 3, pp. 233-241, 2010.

[61] P. Usseglio-Polatera, "Theoretical habitat templets, species traits, and species richness: aquatic insects in the Upper Rhone River and its floodplain," Freshwater Biology, vol. 31, pp. 417-437, 1994.

[62] J. A. Veech, T. O. Crist, and K. S. Summerville, "Intraspecific aggregation decreases local species diversity of arthropods," Ecology, vol. 84, no. 12, pp. 3376-3383, 2003.

[63] D. J. Murrell, D. W. Purves, and R. Law, "Uniting pattern and process in plant ecology," Trends in Ecology and Evolution, vol. 16, no. 10, pp. 529-530, 2001.

[64] R. E. Ricklefs and I. J. Lovette, "The roles of island area per se and habitat diversity in the species-area relationships of four Lesser Antillean faunal groups," Journal of Animal Ecology, vol. 68, no. 6, pp. $1142-1160,1999$.

[65] D. O. Hessen, B. A. Faafeng, V. H. Smith, V. Bakkestuen, and B. Walseng, "Extrinsic and intrinsic controls of zooplankton diversity in lakes," Ecology, vol. 87, no. 2, pp. 433-443, 2006.

[66] J. C. Marshall, F. Sheldon, M. Thoms, and S. Choy, "The macroinvertebrate fauna of an Australian dryland river: spatial and temporal patterns and environmental relationships," Marine and Freshwater Research, vol. 57, no. 1, pp. 61-74, 2006. 

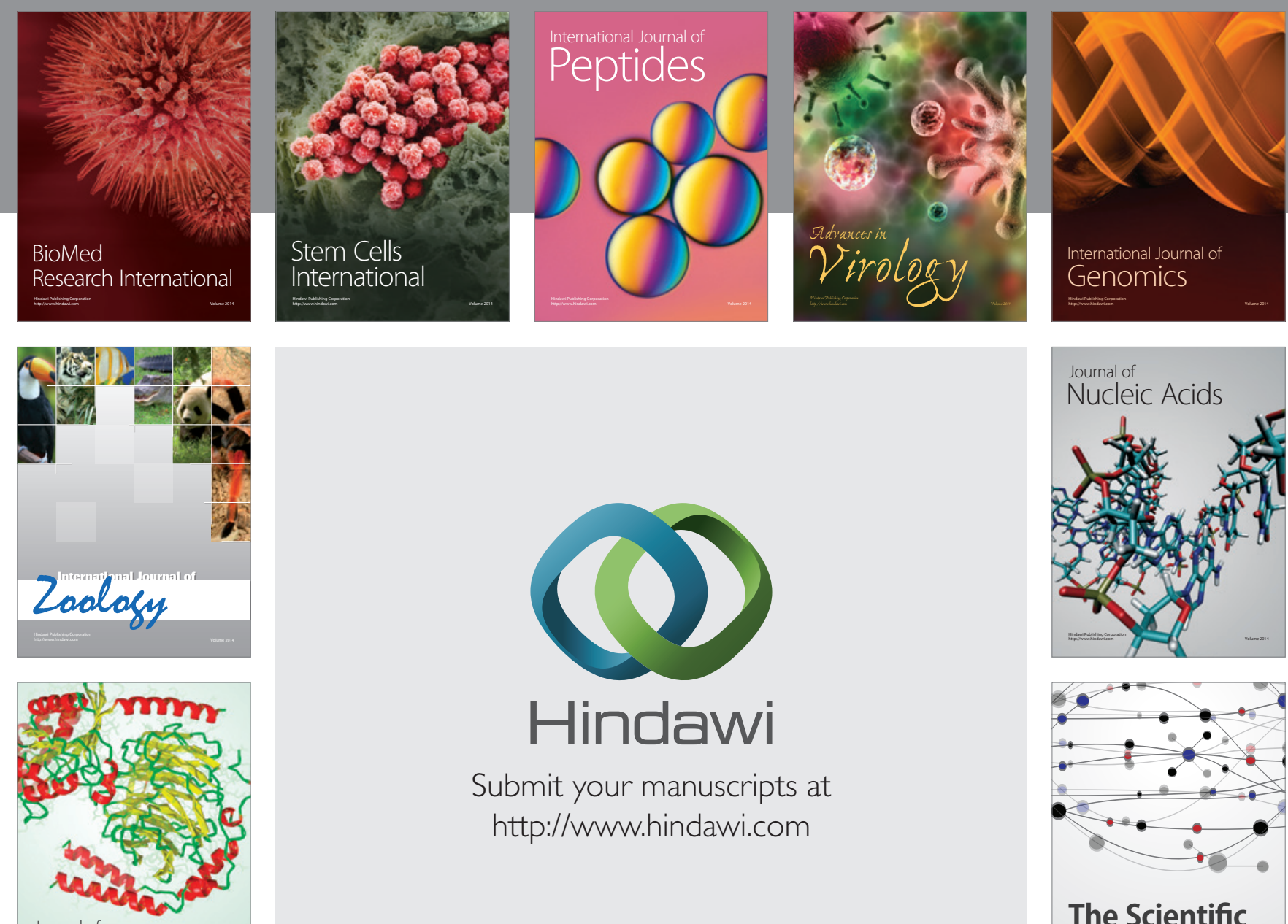

Submit your manuscripts at

http://www.hindawi.com

Journal of
Signal Transduction
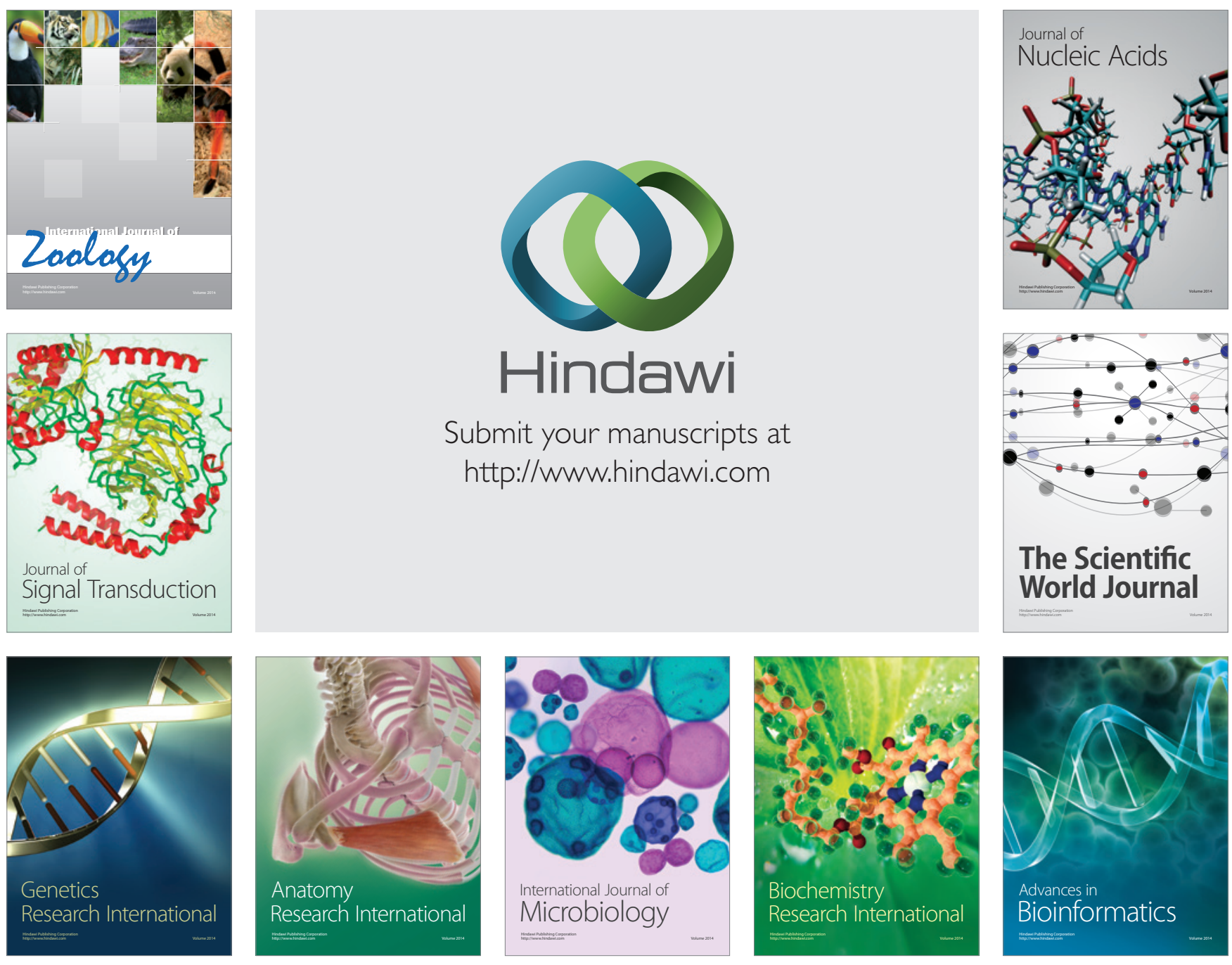

The Scientific World Journal
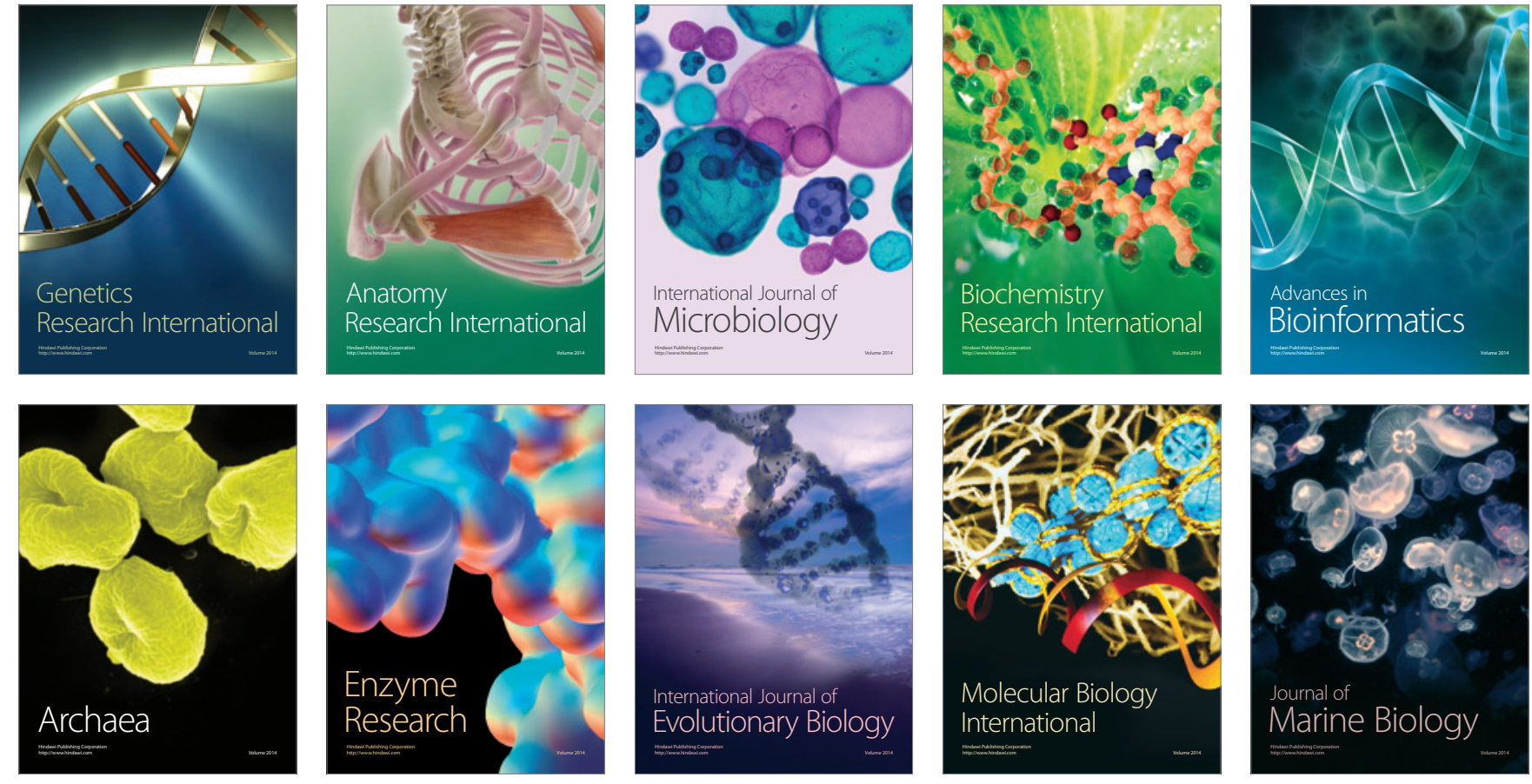